\title{
Assessment of Heavy Metal Contamination and Sediment Quality in the Urban River: A Case Of Ala River in Southwestern - Nigeria
}

\author{
Abata E. O, Aiyesanmi A. F, Adebayo A.O, Ajayi O .O \\ Department of Chemistry, Federal University of Technology, Akure.
}

\begin{abstract}
Ala river is considered as one of the most important irrigation and drinking water resources in Akure, Nigeria. The distribution and accumulation of heavy metals: Cadmium (Cd), Chromium (Cr), Copper $(\mathrm{Cu})$, Iron $(\mathrm{Fe})$, Nicke l(Ni), Lead $(\mathrm{Pb})$ and Zinc $(\mathrm{Zn})$ in sediment were investigated in this river during the raining season between August and September, 2012. The mean concentration of these metals were: $0.09 \mu \mathrm{g} / \mathrm{g}$ for $\mathrm{Cd} ; 20.30 \mu \mathrm{g} / \mathrm{g}$ for $\mathrm{Cr} ; 6.61 \mu \mathrm{g} / \mathrm{g}$ for $\mathrm{Cu} ; 648.04 \mu \mathrm{g} / \mathrm{g}$ for $\mathrm{Fe} ; 1.50 \mu \mathrm{g} / \mathrm{g}$ for $\mathrm{Ni} ; 16.90 \mu \mathrm{g} / \mathrm{g}$ for $\mathrm{Pb} ; 3.78 \mu \mathrm{g} / \mathrm{g}$ for Zn dry weight. The result showed that the average concentrations of heavy metals were ranked as: $F e>$ $\mathrm{Cr}>\mathrm{Pb}>\mathrm{Zn}>\mathrm{Ni}>\mathrm{Cr}>\mathrm{Cd}$. To asses metal contamination in sediment, United State environmental Protection Agency's (USEPA) Guidelines were applied. The concentrations of $\mathrm{Cd}$ in all the stations were moderately polluted. The metals contamination in the sediments were also evaluated by applying Index of geo accumulation(Igeo), contamination factor $\left(C_{f}\right)$ and Degree of contamination. On the basis of the mean values of Igeo, sediments are enriched with metals in the following order: $\mathrm{Pb}>\mathrm{Cd}>\mathrm{Cr}>\mathrm{Cu}>\mathrm{Zn}>\mathrm{Ni}>\mathrm{Fe}$ while according to contamination factor $\left(\mathrm{C}_{f}\right), \mathrm{Cd}, \mathrm{Cr}, \mathrm{Cu}, \mathrm{Fe}, \mathrm{Ni}, \mathrm{Pb}, \mathrm{Zn}$ were at low contamination and in order of $\mathrm{Pb}>$ $\mathrm{Cd}>\mathrm{Cr}>\mathrm{Cu}>\mathrm{Zn}>\mathrm{Ni}>\mathrm{Fe}$. According to degree of contamination $\left(C_{d}\right)$, site 4 has the highest amount of heavy metal contamination while site 9 has the lowest amount of heavy metal contamination. Pearson correlation indicates that $\mathrm{Zn}, \mathrm{Fe}$ and $\mathrm{Ni}, \mathrm{Cr}$ are highly significant $(p<0.01$ ), suggesting that the anthropogenic sources of these metals are closely related in the sediment from Ala river.
\end{abstract}

Keywords - Ala river; sediment; heavy metal; contamination; contamination factor; geo-accumulation index;.

\section{Introduction}

Water is a vital resource to man. Its quantity and quality as well as its management contribute to its sustainability $[1,2]$. Its usage constitutes a major criterion toward sustainable growth and development of a region and its economy [3,4]. Water is one of the most important necessities of life that is required by man, animal and plant. Man uses water for domestic, industrial and agricultural purposes [5]. As noted by researcher, life on earth is impossible without water. It was argued that a man's most urgent used is drinking water [1]. Stating that, man may survive several weeks without food but will die within few days if deprived of water. The past decade has seen remarkable impact of man on the environment due to unprecedented increase in population and rapid rate of urbanization as well as the intensification of the use of fragile and marginal ecosystem [6]. This has led to progressive land and other vital resources degradation and continued desertification of marginal agricultural lands. Understanding and monitoring surface water quality of a region remains a better tool towards promoting sustainable development of water resources within the societal economic and conservational contextual need [7]. Also of importance is the assessment of the human activities that are capable of changing the quality of river water within an urban area [8]. This is necessary, since per capital water demand is increasing while accessibility to available fresh water availability is one that decreases $[9,10]$. These have led to usage of polluted and contaminated water source. Globally, about $80 \%$ of all diseases and death in developing countries was caused by polluted water [11, 12].

Sediments are normally mixtures of several components including different mineral species as well as organic debris. Sediments represent one of the ultimate sinks for heavy metals discharge into the environment $[13,14,15$, and 16]. In the aquatic environment, sediment has a high storage capacity for contaminants. In the hydrological cycle, less than $0.1 \%$ of the metals are actually dissolved in the water and more than $99.9 \%$ are stored in sediments and soils $[17,18]$. Sediments are frequently containing higher concentrations of pollutants. They act as carriers and possible sources of pollution due to the fact that heavy metals are not permanently fixed by them and can be released back to the water by changes in environmental conditions, therefore they may become sufficiently polluted to disrupt natural biological communities. Contamination sediments are known to be responsible for degradation of water quality in the natural waters especially in the shallow and enclosed water systems $[19,20]$. In order to protect the aquatic life community, comprehensive methods for identifying and assessing the severity of sediment contamination have been introduced over the past 10 years [21, 22, and 23] 
Heavy metals, such as arsenic (As), mercury $(\mathrm{Hg})$, Cadmium $(\mathrm{Cd})$, Lead $(\mathrm{Pb})$ and Chronium $(\mathrm{Cr})$, are commonly detected in lakes [24]. Like other aquatic system, heavy metals enter surface water like lakes and river through natural sources (e.g weathering, erosion) and anthropogenic sources (e.g mining, urban and industrial water waste $[25,26]$. At present, heavy metal pollution has become a great environmental concern with their toxicity, persistence, bioaccumulation and biomagnifications in the food chain [27, 28]. Heavy metals contamination in aquatic environment is of critical concern, due to toxicity of metals and their accumulation in aquatic habitats. Trace metals in contrast to most pollutants are not bio-degradable, and they undergo a global ecological cycle in which natural waters are the main pathways. Of the chemical pollutants, heavy metals being non- biodegradable, they can be concentrated along the food chain, producing their toxic effect at points after far removed from the source of pollution [29]. Exposure to heavy metals has linked to several humans' disease such as development retardation or malformation, kidney damage, cancer, abortion, effect on intelligence and behavior, and even death in some cases of exposure to very high concentrations. For human beings, surface water is an important source of water and food. Thus heavy metals in surface water might ultimately have adverse biological effect on human health through drinking water and consuming aquatic products [30, 31]. For these reasons, it would be desirable and imperative to investigate their distribution in urban river like Ala which can provide valuable information of heavy metal pollution and help evaluate potential environmental risks. The aims of this of this study were to: investigate the contamination levels and distributions of heavy metals in surface sediment and evaluate the potential toxicity of the metal concentrations based on sediment quality guidelines.

\section{Materials and Methods-}

\subsection{The study area:}

Akure is the Capital City of Ondo State Nigeria and it is located in the Central Senatorial District of the State [32]. Akure falls between 739000 and 746000 Easting (i.e. between longitude $5^{\circ} 06^{\prime} \mathrm{E}$ and $5^{\circ} 38^{\prime} \mathrm{E}$ ) and between 801500 and 807000 Northing (i .e ., between latitude $7^{\circ} 07^{\prime} \mathrm{N}$ and $737^{\prime} \mathrm{N}$ ) Fig 1.

Akure is bounded in the North by Ifedore local govt, in the west by Ile - Oluji Oke -Igbo local govt, in the South by Idanre local govt and East by Ore - Odigo Local govt. The study area experiences a frequent rainfall between April and July with a short break in August and continues between September and November, with the heaviest rainfall in July. The average daily temperature ranges from $22^{\circ} \mathrm{C}$ during harmattan (December February) to $32^{\circ} \mathrm{C}$ in March which is the peak temperature. The vegetation is tropical rainforest $[33,34]$. The population of the people residing in Akure is about 353,211 [35]

Geography of river Ala: River Ala and tributaries is one of the main tributaries of River Ogbese, South, western, Nigeria. River Ala with total length of about $57 \mathrm{~km}$ has a length of about $14.81 \mathrm{~km}$ with Akure Township (Fig 1). It took its source from north western part of Akure town and flows towards south eastern part of the town. Akure Township dominated the upstream of River Ala while rural towns such as Ilado, Ehinala, Ajegunle, Owode Aiyetoro and Araromi are located in downstream where the water is used for domestic purposes.

\subsection{Samples Collection:}

Sediment samples were collected from ten sites along Ala River (as shown in Fig 1) between the months of August and September 2012.The latitude and longitude for each site were illustrated in Table 1. The samples were carried by polythene bag and transported to the laboratory and stored at temperature of $4^{0} \mathrm{C}$, after which the sediment samples were air - dried for 2 weeks in the Laboratory and sieved through a $1.7 \mu \mathrm{m}$ mesh to remove the debris, then lightly ground in an agate mortal for homogenization and prepared for analysis of heavy metal.

\subsection{Method of extraction}

For heavy metals test, extraction of metals from sediment samples was by mixed acid digestion as described by [36, 37]. Briefly, the digestion was carried out with $20 \mathrm{~mL}$ of a mixture of Conc $\mathrm{HClO}_{4}$ and $\mathrm{HNO}_{3}$ at a 2:1 ratio $(\mathrm{v} / \mathrm{v})$ on a hot plate and the mixture heated to almost dryness, then $20 \mathrm{~mL}$ of $0.5 \mathrm{M} \mathrm{HNO}$ added was and the solution was filtered through Whatman N0 42 filter paper. The filtrate obtained was made up to 50 $\mathrm{mL}$ mark with distilled water in volumetric flask and the solution was analyzed for heavy metals content against those of the blank using a flame atomic absorption Spectrophometer ,M series 600324 v1 .12. The blank was prepared by the method described above except that the sediment was not added. 


\subsection{Study area.}

Table 1 Location of Sediment Sample Collection

\begin{tabular}{|c|c|c|c|}
\hline $\begin{array}{c}\text { Site } \\
\text { No }\end{array}$ & Location & Latitude & Longitude \\
\hline 1 & Aule & $07^{0} 16.45^{\prime} \mathrm{N}$ & $005^{0} 09.99^{\prime} \mathrm{E}$ \\
\hline 2 & Ayedun & $07^{0} 15.82^{\prime} \mathrm{N}$ & $005^{0} 11.48^{\prime} \mathrm{E}$ \\
\hline 3 & Araromi & $07^{0} 15.67^{\prime} \mathrm{N}$ & $005^{0} 11.67^{\prime} \mathrm{E}$ \\
\hline 4 & Oke-Ijebu (Cocola deport & $07^{0} 15.75^{\prime} \mathrm{N}$ & $005^{0} 12.31^{\prime} \mathrm{E}$ \\
\hline 5 & Oke- Ijebu (3- ages Hotel & $07^{0} 16.44^{\prime} \mathrm{N}$ & $005^{0} 12.44^{\prime} \mathrm{E}$ \\
\hline 6 & Fiwasaye & $07^{0} 15.33^{\prime} \mathrm{N}$ & $005^{0} 13.23^{\prime} \mathrm{E}$ \\
\hline 7 & Alagbaka & $07^{0} 15.43^{\prime} \mathrm{N}$ & $005^{0} 12.667^{\prime} \mathrm{E}$ \\
\hline 8 & Odudu & $07^{0} 19.16^{\prime} \mathrm{N}$ & $005^{0} 14.31^{\prime} \mathrm{E}$ \\
\hline 9 & Kojola- Ilado & $07^{0} 11.60^{\prime} \mathrm{N}$ & $005^{0} 17.58^{\prime} \mathrm{E}$ \\
\hline 10 & Ehin- Ala & $07^{0} 11.51^{\prime} \mathrm{N}$ & $005^{0} 18.53^{\prime} \mathrm{E}$ \\
\hline & & & \\
\hline
\end{tabular}

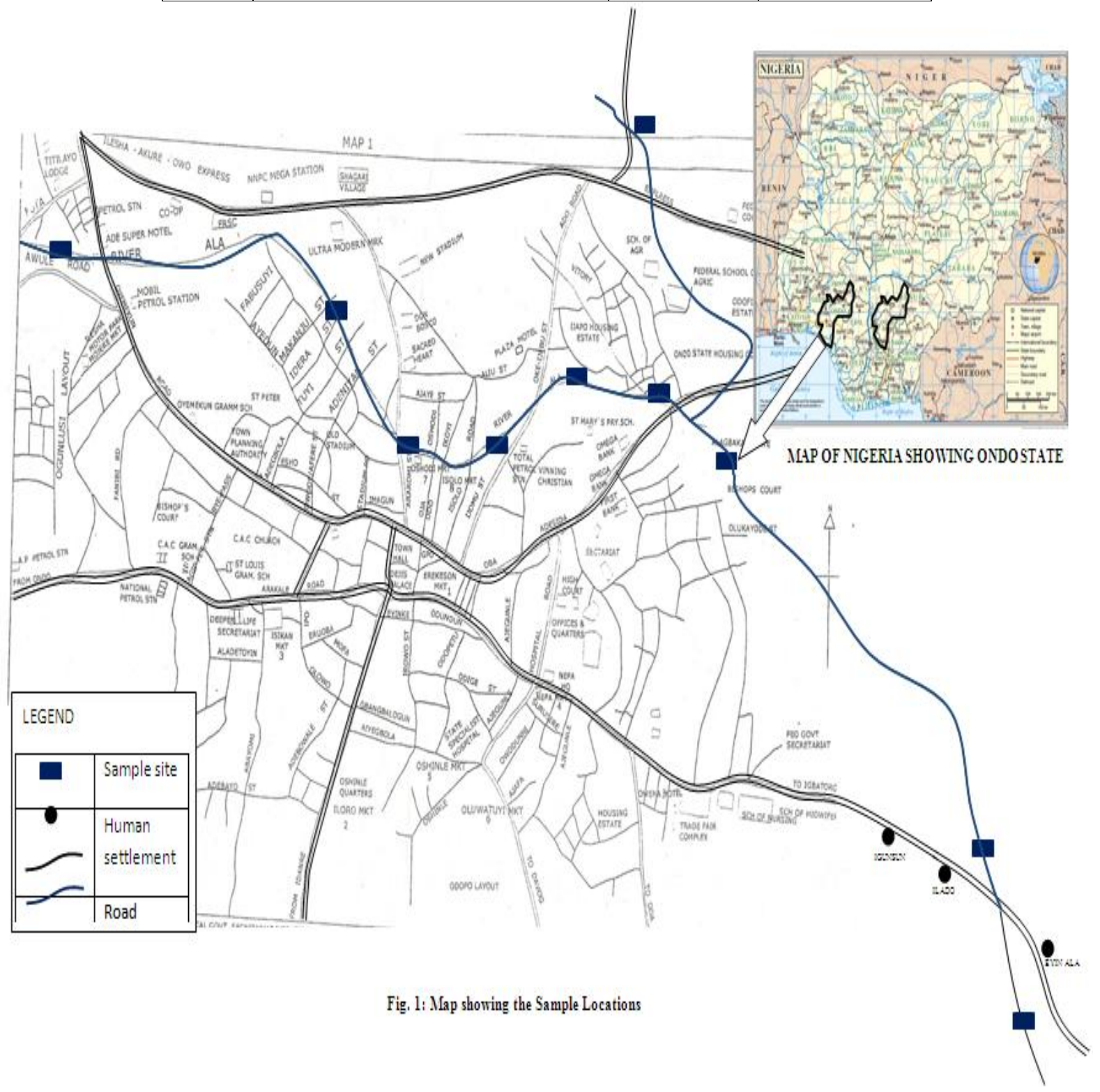




\section{Results And Discussion}

\subsection{Mean Concentration of Heavy Metals Concentration in Sediment ( $\mu \mathrm{g} / \mathrm{g}$ Dry Weight)}

The total concentrations and average values for each site found in sediments in this study are shown in Table 2. Metal contents range over following intervals: Cd: $0.062-0.13 \mu \mathrm{g} / \mathrm{g}$; $\mathrm{Cr}: 3.44-38.05 \mu \mathrm{g} / \mathrm{g}$; $\mathrm{Cu}: 0.62-$ $27.92 \mu \mathrm{g} / \mathrm{g}$; Fe: $475.20-704.24 \mu \mathrm{g} / \mathrm{g}$; Ni: $0.13-2.83 \mu \mathrm{g} / \mathrm{g} ; \mathrm{Pb}: 3.11-80.82 \mu \mathrm{g} / \mathrm{g} ; \mathrm{Zn}: 0.26-6.58 \mu \mathrm{g} / \mathrm{g}$ dry weights. The mean metal contents of the ecosystem studied were: $\mathrm{Cd} 0.09 \mu \mathrm{g} / \mathrm{g}$; Cr: $20.30 \mu \mathrm{g} / \mathrm{g} ; \mathrm{Cu}: 6.61 \mu \mathrm{g} / \mathrm{g}$; Fe: $648.04 \mu \mathrm{g} / \mathrm{g}$; Ni: $1.50 \mu \mathrm{g} / \mathrm{g}$; Pb: $16.90 \mu \mathrm{g} / \mathrm{g} ; \mathrm{Zn}: 1.52 \mu \mathrm{g} / \mathrm{g}$ dry weights. The ranking of the mean metal contents in this area is as follows: $\mathrm{Fe}>\mathrm{Cr}>\mathrm{Pb}>\mathrm{Cu}>\mathrm{Zn}>\mathrm{Ni}>\mathrm{Cd}$. The results obtained in this research indicated that metal contents of Ala River Sediment were lower when compared with sediments in Buriganga River, Bangladesh [38], Western part of Egyptian, Mediterranean Sea [39] and Wadi Al -Arab Dam, Jordan, Shadegan Wetland in Southwest of Iran [40]

The concentration of heavy metals in sediments can be a secondary source of water pollution, once environmental condition is changed [41, 42]. Therefore, an assessment of heavy metal contamination in sediments is an indispensable tool to assess the risk of an aquatic environment. To asses metal concentrations in sediment, Numerical Sediment Quality Guidelines (SQGs) were applied. SQGs include a threshold effect concentration (TEC) and a probable effect concentration (PEC) (Table2). If the metals in sediments are below the TEC, harmful effects are unlikely to be observed. If the metals are above the PEC, harmful effects are likely to be observed [39]. Previous researcher [43], noted in his studies that most of the TEC provide an accurate basis for predicting the absence of sediment toxicity, and most of the PECs, provide an accurate basis for predicting sediment toxicity. In this study, the concentrations of $\mathrm{Cd}, \mathrm{Cr}, \mathrm{Cu}, \mathrm{Ni}, \mathrm{Pb}$ and $\mathrm{Zn}$ in all sediment samples are lower than the proposed TECs, indicating that there are no harmful effects from these metals. On the other hand, the concentrations of Fe exceeded TEC in all samples indicated that these stations were in potential risk.

Table 2 Mean Concentrations of Heavy Metal in Sediment ( $\mu$ g/g Dry weight)

\begin{tabular}{|l|l|l|l|l|l|l|l|}
\hline Site & $\mathrm{Cd}$ & $\mathrm{Cr}$ & $\mathrm{Cu}$ & $\mathrm{Fe}$ & $\mathrm{Ni}$ & $\mathrm{Pb}$ & $\mathrm{Zn}$ \\
\hline 1 & 0.12 & 25.55 & 8.10 & 684.33 & 2.83 & 7.90 & 4.41 \\
\hline 2 & 0.08 & 22.14 & 8.58 & 672.05 & 1.07 & 6.85 & 4.33 \\
\hline 3 & 0.06 & 19.21 & 27.92 & 698.87 & 2.68 & 37.89 & 6.58 \\
\hline 4 & 0.09 & 22.33 & 4.89 & 689.65 & 0.87 & 80.82 & 4.40 \\
\hline 5 & 0.13 & 26.16 & 3.64 & 704.24 & 2.83 & 6.05 & 5.37 \\
\hline 6 & 0.10 & 23.95 & 4.52 & 653.31 & 1.55 & 6.75 & 4.65 \\
\hline 7 & 0.06 & 38.05 & 4.16 & 662.16 & 2.04 & 10.93 & 5.52 \\
\hline 8 & 0.11 & 4.85 & 2.19 & 655.37 & 0.86 & 5.10 & 0.72 \\
\hline 9 & 0.06 & 3.44 & 0.62 & 475.20 & 0.15 & 3.59 & 0.26 \\
\hline 10 & 0.09 & 17.36 & 1.43 & 576.23 & 0.13 & 3.11 & 1.52 \\
\hline Average & 0.09 & 20.30 & 6.61 & 648.04 & 1.50 & 16.90 & 3.78 \\
\hline Max & 0.13 & 38.05 & 8.58 & 704.24 & 2.83 & 80.82 & 6.58 \\
\hline Min & 0.06 & 3.44 & 0.62 & 475.20 & 0.86 & 3.11 & 0.26 \\
\hline TEC & 0.99 & 43.4 & 31.6 & nd & 22.7 & 35.8 & 121 \\
\hline PEC & 4.98 & 111 & 149 & nd & 48.6 & 128 & 459 \\
\hline
\end{tabular}

Note: Tec: Threshold Effect Concentration; PEC: Probable Effect Concentration

\subsection{Assessment of Heavy Metal Concentration}

\subsubsection{Assessment According to United States Environment Protection Agency (USEPA)}

The chemical Contamination in the sediments was evaluated by comparison with the sediment quality guideline proposed by USEPA. These criteria are shown in Table 3. Zn and Ni in all stations under investigation belong to unpolluted class. Site 1, 5 and 7 for $\mathrm{Cr}$, station 2 for $\mathrm{Cu}$, and station 4 for $\mathrm{Pb}$ were considered as moderately polluted. On the other hand $\mathrm{Cd}$ was all moderately polluted in all sites. 
Table 3: EPA guide lines for sediments

\begin{tabular}{|l|l|l|l|l|}
\hline Metal & $\begin{array}{l}\text { Not } \\
\text { Polluted }\end{array}$ & $\begin{array}{l}\text { Moderately } \\
\text { Polluted }\end{array}$ & $\begin{array}{l}\text { Heavily } \\
\text { Polluted }\end{array}$ & $\begin{array}{l}\text { Present } \\
\text { Study }\end{array}$ \\
\hline $\mathrm{Cd}$ & $\ldots .$. & $\ldots .$. & $>6$ & $0.06-0.13$ \\
\hline $\mathrm{Cr}$ & $<25$ & $25-27$ & $>75$ & $3.44-38.05$ \\
\hline $\mathrm{Cu}$ & $<25$ & $25-50$ & $>50$ & $0.62-8.58$ \\
\hline $\mathrm{Ni}$ & $<20$ & $20-25$ & $>50$ & $0.86-2.85$ \\
\hline $\mathrm{Pb}$ & $<40$ & $40-60$ & $>60$ & $3.11-80.82$ \\
\hline $\mathrm{Zn}$ & $<90$ & $90-200$ & $>200$ & $0.26-6.58$ \\
\hline
\end{tabular}

Source: [38].

Table 4: Muller's Classification for the Geo- Accumulation Index.

\begin{tabular}{|l|l|l|}
\hline Igeo & Class & Sediment Quality \\
\hline$\leq 0$ & 0 & Unpolluted \\
\hline $0-1$ & 1 & From unpolluted to moderately polluted \\
\hline $1-2$ & 2 & Moderately polluted \\
\hline $2-3$ & 3 & From moderately to strongly polluted \\
\hline $3-4$ & 4 & Strongly polluted \\
\hline $4-5$ & 5 & From strongly to extremely polluted \\
\hline$>6$ & 6 & Extremely polluted \\
\hline
\end{tabular}

\subsubsection{Assessment According to Geo -accumulation Index (Igeo)}

A common criterion to evaluate the heavy metal pollution in sediments is geo -accumulation index (Igeo), which was originally defined by a researcher to determine metals contamination in sediments, by comparing current concentrations with pre- industrial levels and can be calculated by the following equation [44]

$$
\text { Igeo }=\log 2\left[\frac{C n}{1.5 B n}\right]
$$

Where, $C_{n}$ is the concentration of element, $B n$ is world surface rock average [43]. The factor 1.5 is incorporated in the relationship to account for possible variation in background data due to lithogenic effect. The geo accumulation index (Igeo ) scale consists of seven grades $(0-6)$ ranging from unpolluted to extremely polluted (shown in Table 4).

Table 5: Geo-accumulation index for heavy metal in sediment of Ala river

\begin{tabular}{|l|l|l|l|l|l|l|l|}
\hline Site & $\mathrm{Cd}$ & $\mathrm{Cr}$ & $\mathrm{Cu}$ & $\mathrm{Fe}$ & $\mathrm{Ni}$ & $\mathrm{Pb}$ & $\mathrm{Zn}$ \\
\hline 1 & -1.91 & -2.40 & -3.06 & -6.68 & -5.17 & -1.92 & -5.01 \\
\hline 2 & -2.49 & -2.61 & -2.98 & -6.70 & -6.57 & -2.13 & -5.04 \\
\hline 3 & -2.91 & -2.81 & -1.27 & -6.65 & -5.25 & 0.34 & -4.43 \\
\hline 4 & -2.32 & -2.60 & -3.79 & -6.65 & -6.87 & 1.43 & -5.01 \\
\hline 5 & -1.79 & -2.37 & -4.21 & -6.64 & -5.17 & -2.31 & -4.73 \\
\hline 6 & -2.17 & -2.49 & -3.90 & -6.74 & -6.04 & -2.15 & -4.93 \\
\hline 7 & -2.91 & -1.83 & -4.02 & -6.72 & -5.64 & -1.46 & -4.69 \\
\hline 8 & -2.03 & -4.80 & -4.95 & -6.74 & -6.89 & -2.56 & -7.62 \\
\hline 9 & -2.91 & -5.29 & -6.77 & -7.20 & -9.41 & -3.06 & -9.09 \\
\hline 10 & -2.32 & -2.96 & -5.56 & -6.93 & -9.62 & -3.27 & -6.55 \\
\hline Mean & -2.37 & -3.02 & -4.05 & -6.75 & -6.66 & -1.71 & -5.71 \\
\hline
\end{tabular}

According to the Muller scale, the calculated results of $\mathrm{I}_{\text {geo }}$ Values (shown in Table 5 ) indicate, for $\mathrm{Pb}$ sediment quality be considered as moderately polluted $\left(1 \leq \mathrm{I}_{\mathrm{geo}}<2\right)$ for site 4 , but sediment quality ranges from unpolluted to moderately polluted $\left(0 \leq \mathrm{I}_{\text {geo }}<1\right)$ for site 3 and unpolluted $\left(\mathrm{I}_{\text {geo }}<0\right)$ for all other sites. $\mathrm{Cd}, \mathrm{Cr}, \mathrm{Cu}, \mathrm{Fe}, \mathrm{Ni}, \mathrm{Zn}$ 
were unpolluted in all the sites $\left(\mathrm{I}_{\text {geo }}<0\right)$. On the basis of the mean values of Igeo, sediments are enriched for metals in the following order: $\mathrm{Pb}>\mathrm{Cd}>\mathrm{Cr}>\mathrm{Cu}>\mathrm{Zn}>\mathrm{Ni}>\mathrm{Fe}$.

Table 6. Contamination factor $\left(C_{f}\right)$ and Degree of contamination $\left(C_{d}\right)$ for Ala River.

\begin{tabular}{|l|l|l|l|l|l|l|l|l|}
\hline Site & $\mathrm{Cd}$ & $\mathrm{Cr}$ & $\mathrm{Cu}$ & $\mathrm{Fe}$ & $\mathrm{Ni}$ & $\mathrm{Pb}$ & $\mathrm{Zn}$ & $\begin{array}{l}\text { Degree of } \\
\text { Contamination } \\
\left(\mathrm{C}_{\mathrm{d}}\right)\end{array}$ \\
\hline 1 & 0.40 & 0.28 & 0.18 & 0.015 & 0.042 & 0.40 & 0.046 & 1.36 \\
\hline 2 & 0.27 & 0.25 & 0.19 & 0.014 & 0.016 & 0.34 & 0.046 & 1.13 \\
\hline 3 & 0.20 & 0.21 & 0.62 & 0.015 & 0.039 & 1.89 & 0.069 & 3.04 \\
\hline 4 & 0.30 & 0.25 & 0.11 & 0.015 & 0.013 & 4.04 & 0.046 & 4.77 \\
\hline 5 & 0.43 & 0.29 & 0.08 & 0.015 & 0.042 & 0.30 & 0.057 & 1.22 \\
\hline 6 & 0.33 & 0.27 & 0.10 & 0.014 & 0.023 & 0.34 & 0.049 & 1.13 \\
\hline 7 & 0.20 & 0.42 & 0.09 & 0.014 & 0.030 & 0.55 & 0.058 & 1.38 \\
\hline 8 & 0.37 & 0.05 & 0.04 & 0.014 & 0.013 & 0.26 & 0.008 & 0.76 \\
\hline 9 & 0.20 & 0.04 & 0.01 & 0.010 & 0.002 & 0.18 & 0.003 & 0.45 \\
\hline 10 & 0.30 & 0.19 & 0.03 & 0.012 & 0.002 & 0.16 & 0.016 & 0.71 \\
\hline Mean & 0.30 & 0.22 & 0.15 & 0.014 & 0.022 & 0.85 & 0.04 & 1.59 \\
\hline
\end{tabular}

The contamination factors $\left(C_{f}\right)$ or enrichment ratio (ER) and the degree of contamination $\left(C_{d}\right)$ are used to determine the contamination status of sediment in the present study. $\left(\mathrm{C}_{\mathrm{f}}\right)$ values for describing the contamination level are shown in Table 6. The contamination factors are calculated according to the eq. 2 and the degree of contamination $\left(\mathrm{C}_{\mathrm{d}}\right)$ was defined as the sum of all contamination factors. Calculated contamination factor $\left(\mathrm{C}_{\mathrm{f}}\right)$ and degree of contamination $\left(\mathrm{C}_{\mathrm{d}}\right)$ for this study is shown in the Table 6.

$$
\mathrm{C}_{f}=\frac{\text { Measured concentration }}{\text { Background concentration }}
$$

Where, Background value of the metal $=$ world surface rock average [45]. In the present study, maximum contamination factor was found in the site 4 where the degree of contamination is 4.77 . Contamination factor, $\mathrm{Cf}>4$ (indicates considerate contamination) is found in site 4 for $\mathrm{Pb}$ while in Site $3, \mathrm{C}_{\mathrm{f}}>1$ for $\mathrm{Pb}$ indicates moderately contamination. Site 4 and Site 3 are in the downstream of the river where dumping of refuse, agriculture wastes, industrial effluents and industrial activities are being channeled to. The remaining sites have a contamination factor $(\mathrm{Cf})<1$ which indicates low contamination [46] in Table 7. On the basis of the mean valve of $\mathrm{C}_{\mathrm{f}}$, sediment is enriched for metals in the following order: $\mathrm{Pb}>\mathrm{Zn}>\mathrm{Cd}>\mathrm{Cr}>\mathrm{Cu}>\mathrm{Ni}>\mathrm{Fe}$.

Table 7: Contamination Factor and Level of Contamination (Hakanson 1980)

\begin{tabular}{|l|l|}
\hline Contamination Factor $\left(\mathrm{C}_{\mathrm{f}}\right)$ & Level of Contamination \\
\hline $\mathrm{C}_{\mathrm{f}}<1$ & Low contamination \\
\hline $1 \leq \mathrm{C}_{\mathrm{f}}<3$ & Moderate contamination \\
\hline $3<\mathrm{C}_{\mathrm{f}}<6$ & Considerate contamination \\
\hline $\mathrm{C}_{\mathrm{f}}>6$ & Very high contamination \\
\hline
\end{tabular}

Table 8: Pearson's correlation coefficient among the selected heavy metals

\begin{tabular}{|l|l|l|l|l|l|l|l|}
\hline & $\mathrm{Cd}$ & $\mathrm{Cr}$ & $\mathrm{Cu}$ & $\mathrm{Fe}$ & $\mathrm{Ni}$ & $\mathrm{Pb}$ & $\mathrm{Zn}$ \\
\hline $\mathrm{Cd}$ & 1 & & & & & & \\
\hline $\mathrm{Cr}$ & 0.0461 & 1 & & & & & \\
\hline $\mathrm{Cu}$ & -0.326 & 0.139 & 1 & & & & \\
\hline $\mathrm{Fe}$ & 0.406 & $0.601^{*}$ & 0.453 & 1 & & & \\
\hline $\mathrm{Ni}$ & 0.309 & $0.602^{*}$ & $0.535^{*}$ & $0.7232^{*}$ & 1 & & \\
\hline $\mathrm{Pb}$ & -0.176 & 0.125 & 0.359 & 0.359 & 0.013 & 1 & \\
\hline $\mathrm{Zn}$ & -0.012 & $0.804^{* *}$ & $0.624^{*}$ & $0.781^{* *}$ & $0.804^{* *}$ & 0.344 & 1 \\
\hline
\end{tabular}

Note $: *$ is significant at $\mathrm{p}<0.05 ; * *$ correlation is highly significant at the $\mathrm{p}<0.01$ 
Correlation Coefficient " $\mathrm{r}$ " is one of the most important statistical tests to evaluate the strength or weakness relationships among metals in this study. Significant correlations between the contaminants of $\mathrm{Cr}$ and $\mathrm{Fe}$ (0.601), $\mathrm{Cr}$ and $\mathrm{Ni}(0.602), \mathrm{Cu}$ and $\mathrm{Ni}(0.535), \mathrm{Cu}$ and $\mathrm{Zn}(0.624)$, Fe and $\mathrm{Ni}(0.723)$ at $\mathrm{p}<0.05$ and highly significant at $\mathrm{p}<0.01$ between $\mathrm{Cr}$ and $\mathrm{Zn}(\mathrm{r}=0.8042), \mathrm{Fe}$ and $\mathrm{Zn}(\mathrm{r}=0.7809)$, Ni and $\mathrm{Zn}(\mathrm{r}=0.8037)$, could indicate the same or similar source input or similar enrichment mechanism [47], suggesting that the anthropogenic sources of these metals are closely related in the sediment from Ala river.

\section{Conclusions}

The results of this study provide valuable information on metal contents of sediments from different sampling sites of Ala River. Moreover these results can also be used to test the chemical quality of the surface water sediment in order to evaluate the possible risk to the river of this area. The order of the mean concentration of tested heavy metals: $\mathrm{Fe}>\mathrm{Cr}>\mathrm{Pb}>\mathrm{Cu}>\mathrm{Zn}>\mathrm{Ni}>\mathrm{Cd}$. USEPA guideline, Geo -accumulation Index, Contamination factor and degree of contamination, are successfully applied for the assessment of contamination. The result obtained from Igeo method emphasized that sediments are enriched with metals in the following order: $\mathrm{Pb}>\mathrm{Cd}>\mathrm{Cr}>\mathrm{Cu}>\mathrm{Zn}>\mathrm{Ni}>\mathrm{Fe}$ while according factor $\left(\mathrm{C}_{\mathrm{f}}\right), \mathrm{Cd}, \mathrm{Cr}, \mathrm{Cu}, \mathrm{Fe}, \mathrm{Ni} \mathrm{Zn}$ were at low contamination. It could be concluded that both Igeo and $\mathrm{C}_{\mathrm{f}}$ are powerful tools for the assessment of contamination of heavy metal. According to USEPA: for $\mathrm{Cd}$, the sediment samples are moderately polluted; Considering all assessment criteria, only $\mathrm{Cd}$ is responsible for moderately amount of heavy metal contamination while $\mathrm{Cr}, \mathrm{Cu}, \mathrm{Fe}, \mathrm{Ni}, \mathrm{Pb}, \mathrm{Zn}$ are responsible for low contaminations. According to degree of contamination, Site 4 has the highest amount of heavy contamination and Site 9 has the lowest amount of heavy metal contamination. This is plausible because site 4 is in the downstream area of river where dumping of refuse, agriculture wastes, industrial effluents and others industrial activities are channeled to while Site 9 is in the upstream of the river where there is little or no agricultural, domestics and industrial activities.

\section{Acknowledgement}

The authors are grateful to the Dr. Olasehinde E. F. of Dept. of Chemistry, FUTA for taking his time to preview the manuscripts and Mr Adeleye Dayo Oluwaseun of marine and oceanographic institution for his technical assistance on metal analysis.

\section{References}

[1] Faniran, A., 1991. Water Resources Development in Nigeria. University of Ibadan, Ibadan pp: 95

[2] UNESCO -WWAP, 2003. Water for people, water for life WHO /UNCFF (2002). The United Nation World Water Development Report (UNESCOWWAP).

[3] Katte, V. Y., Fonteh and G.N. Guemuh,2003. Domestic water quality in urban centers in Cameroon: A case study of discharge in the West Province. Afr. Water J., 25: 45 -56.

[4] Gleitsmann, B. A., M. M kroma and T. steenhuis, 2007. Analysis of a rural water supply project in three communities in Mali: Participation and Sustainability, Nat. Resour. Forum., 31 :142 -150.

[5] Ayeni, A. O., Balogun I. I and Soneye A. S. O (2011). Seasonal Assessment of Physico - chemical concentration of polluted Urban River: a case of Ala River in southwestern -Nigeria.

[6] Olorunfemi, J. F and H. I. Jimoh, 2000. Anthropogenic Activities and the Environment. In: contemporary issue in Environment studies, Jimoh, H. I and I.P., Ifabiyi (Eds) Haytee Press, Ilorin.

[7] Ifabiyi, I. P., 1997. Variation in water gravity with rainfall incidences: A case study of Ogbe stream Ile -Ife. Res. Publ. Geography , $6: 139-144$.

[8] Ayeni, O. A., I. Balogun and O. Adeaga, 2006. Impact of selected land- use types on surface water quality downstream of Asa dam in Kwara state, Nigeria. Proceedings of International conference in Infrastructure Development and the Environment (ICIDEN, 2006), sept. $10-15$.

[9] Sullivan, C. A., J. R. Meigh, A. M. Giacomello, T. Fediw and P. Lawrence et al., 2003. The wter poverty index: Development a nd application at the community scale: Nat. Resour. Forum, 27: $189-199$.

[10] Watson, S. B and Lawrence J, 2003. Drinking water quality and sustainability. Water Qual. Res. J. Canada, $38: 3$ - 13.

[11] Awake, 2001. Water, will there be enough? Water Tower Bible and Tract society, Pennsylyvaania June22, pp: 4 -13.

[12] Aderibigbe, S. A., A. O. Awoyemi and G. K. Osagbemi, 2008. Availability, adequacy and quality of water supply in Ilorin metropolis, Nigeria. Eur. J. Scientific Res.,23: 528 -536.

[13] Gibbs, R. J., 1977. Transport phases of transition metals in the Amazon and Yukon Rivers. Geol. Soc. Am. Bull. 88, 829 - 843.

[14] Luoma, S. N., Bryan, G. W.,1981. A statistical assessment of the form of trace metals in oxidized estuarine sediments employing chemical extractants. Sci. Total Environ. 17, 165- 196.

[15] Bettinetti, R., Giarei, C., Provini, A., 2003. A chemical analysis and sediment toxicity bioassays to assess the contamination of the River Lambro (Northern Italy). Arch. Environ. Contam. Toxicol. 45, 72- 80.

[16] Hollert, H., Keiter,S., Konig, N., Rudolf, M., Braunbeck, T., 2003. A new sediment contact assay to assess particulate- bound pollutants using Zebra fish (Danio rerio) embryos. J. Soils Sediments 3, 197-207.

[17] Karbassi A. R, Nouri J, Ayah G. O (2007). Flocculation of Cu, Zn, Pb and Ni during mixing of Talar river water with the Caspian seawater. Int. J. Environ. Res. 1(1): 66-73.

[18] Pradit S, Wattayakom G, Angsupanich S, Baeyens W, Leermakers M(2009). Distribution of Trace Elements in Sediments and Biota of Songkhla Lake, Southern Thailand. Water, Air, Soil Pollut. 22 MAY.

[19] Toluna L. G, Okaya O.S, Gainesb A. F, Tolayc M, Tuefekceia H, Koratlod N (2001). The pollution status and the toxicity of surface sediments in Izmit Bay (Marmara Sea), Turkey. Environ. Int. 26 : 63-168. 
[20] Venugopal T, Giridharan L, Jayaprakash M (2009). Characterization and Risk Assessment Studies of Bed Sediments of River Adyar- An Application of Speciation Study. Int. J. Environ. Res. 3(4) :581-598.

[21] Van de Guchte, C, 1992. The sediment quality Triad: an integrated approach to assess contaminated sediments. In: Newman, P. J., Piavaux, M. A., Sweeting, R. A (Eds), River Water Quality, Ecological Assessment and Control. Brussels, ECSC - EEC -EAEC, pp. $417-423$.

[22] Chapman, P. M 2000. The sediment quality triad: then, now tomorrow. Int. J. Environ. Pollut. 13, $351-360$.

[23] HU, Ying, QI Shihua, WU Chenxi, KE Yanping, CHEN Jing, Wei CHEH, GONG Xiangyi, 2012. Preliminary assessment of heavy metal contaminations in surface water and sediments from Honghu Lake, East Central China.

[24] Anshumali, Ramanatha A. L, Singh G, Ranjan R, Tripathi P (2009). Chemodynamics of trace mletal fractions in surface sediments of the Pandoh Lake, Lesser Himalaya, India. Environ Geo, 57(8); 1865-1879.

[25] Zorer O. S, Ceylan H. Dogru M(2008).Assessment of some trace heavy metals and radioactivity concentration in water of Bendimahi River Basin (Van, Turkey), Environ Monit Assss, 147 (1 -3): 183 -190

[26] Alhas E, Oymak S.A , Karadede Akin H (2009). Heavy metal concentrations in two barb, Barbius Xanthopterus and Barbus rajanorum mystaeus from Ataturrk Dam lake, Turkey. Environ Monit Assess 148 (1 -4): 11 -18.

[27] Li S. Y, Xu Z. F, Cheng X. L, Zhang Q. F (2008). Dissolved trace elements and heavy metals in the Danjiangkou reservoir, China. Environ Geo, 55(5): $977-983$.

[28] Yuan H. Z, Shen J, Liu E. F, Wang J. J, Meng X. H (2011). Assessment of nutrients and heavy metals enriched in surface sediments from Taihu Lakes a eutrophic shallow lake in China. Environ Geochem Health, 33(1): 67 -81.

[29] Tilzer M. M and Khodker M, (1993). Hypertrophic and polluted freshwater ecosystems: Ecological basis for water resources management, “ Dept. Of Botany, Dhaka University, Bangladesh, 1993.

[30] Huang, X, Hu J, LI C, Deng J, Long J, Qin F (2009). Heavy metal pollution and potential ecological risk assessment of sediments from Baihua lake, Guizhou, China. Int J. Enviiron Health Res, 19 (6): 405 -419.

[31] Zang M, Cui L, Sheng L, Wang Y (2009). Distribution and enrichment of heavy metals among sediments, water body and plants in Hengshuihu Wetlandof North China. Ecol. Eng, 35 (4): 563 -569.

[32] Federal Office of Statistic, 1992. Federal Republic of Nigeria Official Gazette. Vol . 94,Federal Government Printer, Lagos, Nigeria.

[33] Barbour, K, J. S Oguntoyinbo, J. O. C Onyemelukwe and J. C. Nwafor, 1992. Nigeria in Maps. Nigerian Publisher, Ibadan.

[34] Uluocha, N. O. and G. Ekop, 2002. Nigeria:Geography. In: History and Cultures of Nigeria up to AD 2000, Osuntokun A. D.Aworawo and F. Masajuwa (Eds): Frankad Publishers, Lagos, Nigeria.

[35] Federal Bureau of Statistics, 2007. Federal Republic of Nigeria Official Gazette. Vol 94, Federal Government Printer, Lagos, Nigeria.

[36] Lacatusu, R. (2000). Appraising levels of soil contamination and pollution with heavy metals. European soil Bureau, Research Report No 4.

[37] Chale, F. M. M (2002). Trace metal concentrations in water, sediment and Fish tissue from Lake Tanganyika. Sci. total Envion. $299,115-121$.

[38] Saha P. K and Hossain M. D (2011). Assessment of Heavy Metal Contamination and Sediment Quality in the Buriganga River, Banbladesh.

[39] Ahdy Hoda H. H and Khaled Azza, 2009. Heavy Metals Contamination in Sediments of theWestern Part of Egyptian Mediterranean Sea.

[40] Ghrefat Habes and Yusuf Nigem, 2006. Assessing Mn, Fe, Cu, Zn, and pollution in bottomsediments of Wadi Al- Arab Dam, Jordan.

[41] Chen, W, Tan, S. K, Tay,J. H (1996). Distribution, Fractional composition and release of sediment- bound heavy metals in tropical reservoirs. Water, Air Soil Pollution, 92: 273 -287.

[42] Cheung, K. C, Poon B. H. T, Lan C.Y and Wong M. H (2003). Assessment of metal and nutrient concentrations in river water and sediment collected from the cities in the Pearl River Delta, South China. Chemosphere, 52: 1431 -1440.

[43] MacDonald, D. D, Ingersoll C. G and Berger T. A (2000). Development and evaluation of consensus - based sediment quality guidelines for freshwater ecosystems. Archives of Environmental and Contamination Toxicology, 39: 20-31.

[44] Muller, G. 1979. Heavy metals in the sediment of the Rhine-Changes seity. 1971. Umsch. Wiss. Tech., 79: $778-783$.

[45] Martin J. M and Meybeck M (1979).” Elemental mass balance of materials carried by major world rivers," Mar Chem, 7, pp. 173 206.

[46] Hakanson, L., 1980. An ecological risk indexes for aquatic pollution control a sedimentological approaches. Water Research, 14: $975-1001$.

[47] Nguyen H. L, Braun M, Szaloki I, Baeyens W, van Grieken R, leermakers m (2009). Tracing the metal pollution history of the Tisza River through the analysis of a sediment depth profile. Water, Air, Soil pollut, 200(1): 119-132. 